Images in...

\title{
Traumatic epidural pneumorrhachis
}

Roberto Copetti, Giampiero Mattei

Emergency Department, San Antonio Abate Hospital, Tolmezzo, Italy

Correspondence to Roberto Copetti, robcopet@tin.it

\section{DESCRIPTION}

A 57-year-old man was admitted to the emergency department with blunt thoracic and abdominal trauma after being hit by a tree.

CT of the thorax and abdomen was performed.

Abdominal CT showed a large retroperitoneal haematoma secondary to an injury of celiac trunk; thoracic CT showed a right haemo-pneumothorax, a pneumomediastinum, a large basal lung contusion, a small dorsal right subcutaneous emphysema, the fractures of third, fourth and fifth right ribs (figure 1) and some small air bubbles in the spinal canal between the second and the fifth thoracic vertebra (figure 2).

Pneumorrhachis (air within the spinal canal) is an extremely rare manifestation of severe trauma.

Air within the spinal canal may occur in the epidural or subarachnoid space. ${ }^{1-4}$

The latter is frequently associated with more serious injuries like skull fractures and thoracic spine fractures and is almost always associated with pneumocephalus. In skull fractures subarachnoid pneumorrhachis is the consequence of pneumocephalus, while in spine fractures

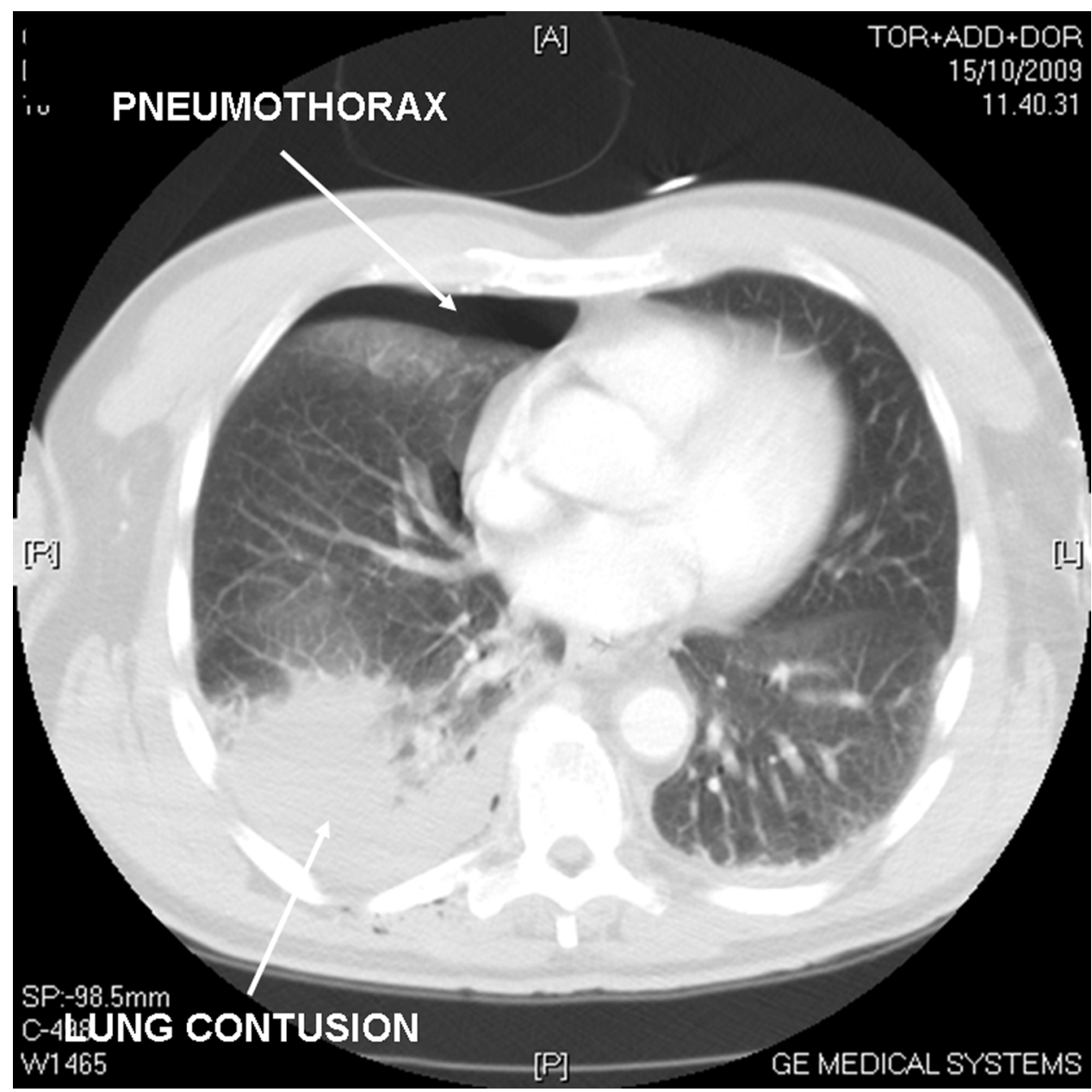

Figure 1 CT scan of the thorax showing right pneumothorax and lung contusion. 


\section{BMJ Case Reports}

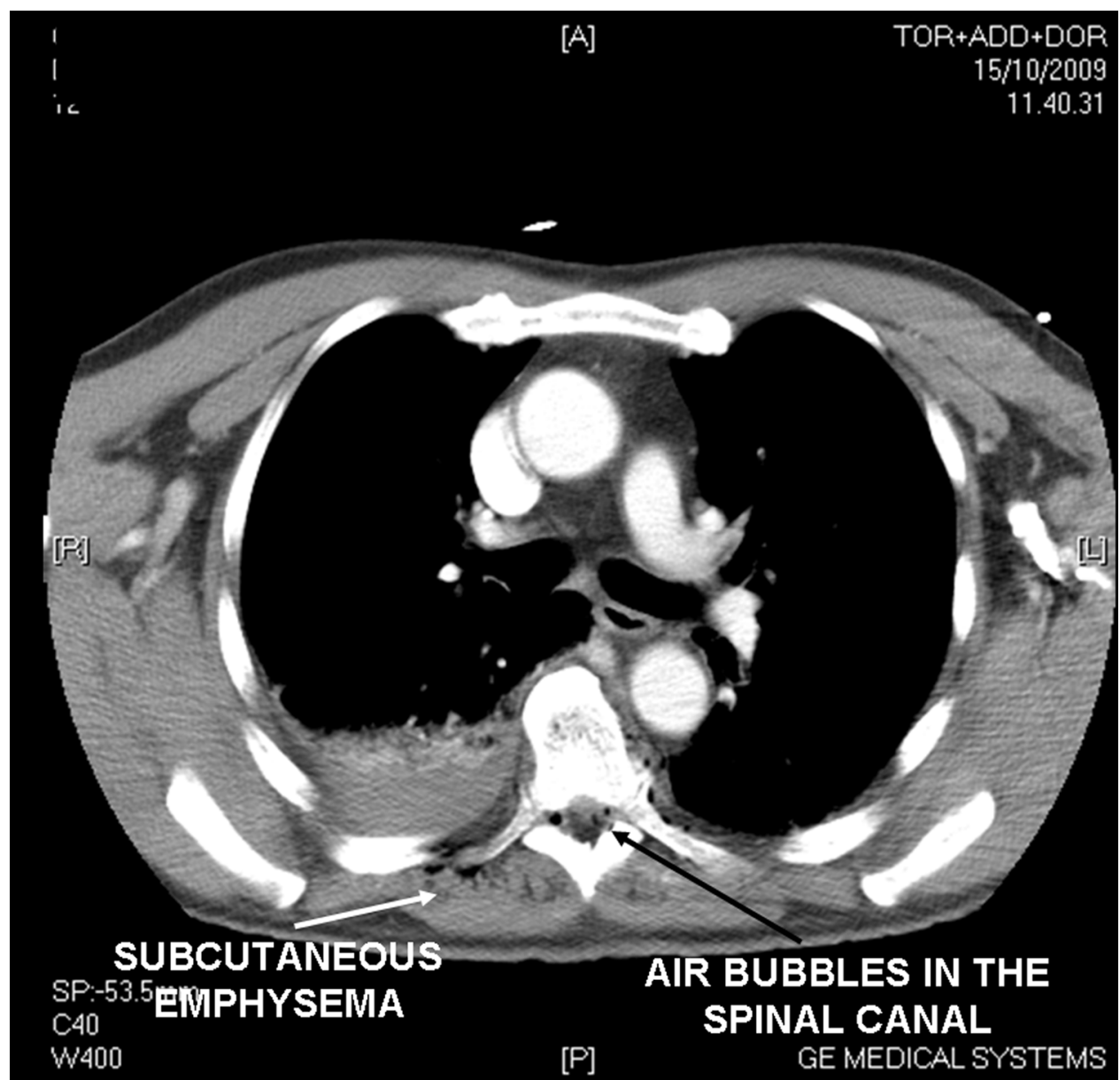

Figure 2 CT scan of the thorax showing dorsal right subcutaneous emphysema and small air bubbles in the spinal canal.

pneumocephalus is caused by air that migrates to the brain from subarachnoid space.

Epidural pneumorrhachis is less frequent and is often associated with traumatic pneumothorax or traumatic pneumomediastinum. The mechanism through which pneumorrhachis occurs is when air present in the posterior mediastinum dissects along fascial planes from the posterior mediastinum, through the neural foramina, into the epidural space behind the driving pressure of a pneumothorax or pneumomediastinum. ${ }^{24}$

Pneumorrhachis has been described also in nontraumatic events like violent coughing, physical exertion, prolonged and forceful emesis, inhalational drug abuse ('ecstasy' and marijuana) and surgical manipulations as well as spontaneously. ${ }^{2}$

Even thought traumatic pneumorrhachis is asymptomatic and no treatment is necessary because the driving force of a pneumothorax or pneumomediastinum can push only small volumes of air into the epidural space, its presence indicates a severe trauma that requires careful monitoring of the patient.

Competing interests None.

Patient consent Obtained.

\section{REFERENCES}

1. Goh BK, Yeo AW. Traumatic pneumorrhachis. J Trauma 2005;58:875-9.

2. Oertel MF, Korinth $\mathrm{MC}$, Reinges $\mathrm{MH}$, et al. Pathogenesis, diagnosis and management of pneumorrhachis. Eur Spine J 2006;159(Suppl 5):636-43.

3. Gibikote $\mathbf{S}$, Wray A, Fink AM. Pneumorrhachis secondary to traumatic pneumomediastinum in a child. Pediatr Radiol 2006:36:711-13.

4. Akay S, Bayram B. Traumatic pneumorrhachis: a rare entity of trauma. Int $J$ Emerg Med 2008;1:53. 


\section{BMJ Case Reports}

This pdf has been created automatically from the final edited text and images.

Copyright 2010 BMJ Publishing Group. All rights reserved. For permission to reuse any of this content visit http://group.bmj.com/group/rights-licensing/permissions. BMJ Case Report Fellows may re-use this article for personal use and teaching without any further permission.

Please cite this article as follows (you will need to access the article online to obtain the date of publication).

Copetti R, Mattei G. Traumatic epidural pneumorrhachis. BMJ Case Reports 2010;10.1136/bcr.01.2010.2692, date of publication

Become a Fellow of BMJ Case Reports today and you can:

- Submit as many cases as you like

Enjoy fast sympathetic peer review and rapid publication of accepted articles

Access all the published articles

- Re-use any of the published material for personal use and teaching without further permission

For information on Institutional Fellowships contact consortiasales@bmjgroup.com

Visit casereports.bmj.com for more articles like this and to become a Fellow 